DOI: 10.5817/CZ.MUNI.P210-6840-2014-73

\title{
THE ROLE OF NON-PROFIT ORGANIZATIONS IN A REGIONAL DEVELOPMENT IN A CONTEXT OF SOCIAL COHESION: THE CASE OF ICELAND
}

\section{ROLA NEZISKOVÝCH ORGANIZÁCIÍ V ROZVOJI REGIÓNOV Z HōADISKA SOCIÁLNEJ SÚDR GNOSTI: PRÍPAD ISLANDU}

\section{ING. MÁRIA SVIDRO@VÁ, PHD.}

\author{
Katedra verejnej ekonomiky a regionálneho rozvoja $\mid$ Depart. of Public Economics and Reg. Development \\ Ekonomická fakulta Faculty of Economics \\ Univerzita Mateja Bela v Banskej Bystrici Matej Bel University Banska Bystrica \\ $\triangle$ Tajovského 10, 97401 Banská Bystrica, Slovak Republic
}

E-mail: maria.svidronova@umb.sk

\begin{abstract}
Annotation
The non-profit sector is not only a supplement for public sector and business sector but non-profit organizations are equal partners in the provision of public services, especially in the local communities where they better reflect the particular problems and requirements. Operation of nonprofit organizations at the community level involves citizens and initiates cooperation with the government at the local level. In this paper we map the non-profit sector, its operation and contribution to regional development in the context of social cohesion in specific conditions in Iceland. The paper is a part of the project "Love your hater", which promotes the exchange of experiences among NGOs in Slovakia and Iceland in their management and financing, as well as exchange of experience on specific activities aimed at mitigation of racism and discrimination and improving living conditions in the regions.
\end{abstract}

\section{Key words}

non-profit organizations, third sector, regional development, social cohesion

\section{Anotácia}

Neziskový sektor nie je len doplnkom pre verejný sektor a ziskový sektor, ale neziskové organizácie sú rovnocenným partnerom pri poskytovaní verejných sluğieb, najmä v miestnych komunitách, kde lepğie reflektujú na konkrétne problémy a poǵadavky. Pôsobením na úrovni komunít tak neziskové organizácie aktivizujú ob! anov a spolupracujú s vládou na miestnej úrovni. V príspevku mapujeme neziskový sektor, jeho fungovanie a prínos $v$ rozvoji regiónov zhădiska budovania sociálnej súdrǵnosti v ġpecifických podmienkach na Islande. Príspevok je súl asડ̌su projektu ĂLove your haterñ, ktorý podporuje výmenu skúseností medzi neziskovými organizáciami na Slovensku a na Islande $v$ oblasti ich manağmentu a financovania, ako aj výmenu skúseností v oblasti ǵpecifických aktivít zameraných na zmierŔovanie rasizmu a diskriminácie a zlepǵsvania ğvotných podmienok $v$ regiónoch.

\section{Klị̣ová slova}

neziskové organizácie, tretí sektor, regionálny rozvoj, sociálna súdrǵnosડ̌

JEL classification: $L 31$, O18, P48 


\section{Introduction}

Non-profit organizations have many names as the scope of their activities is so diverse that it is not possible to define these organizations by a single term. Therefore a broader description of the characteristics of non-profit organizations is preferred. Worldwide a definition by Anheier and Salamon (1999) has been accepted. This definition is also called the structural-operational definition and it describes the non-profit organization with five main characteristics: institutionalization, independence, non-profit, self-government, voluntary participation. In many countries within this definition usually belong civic associations, foundations, public benefit organizations but also other legal types that vary from country to country. The definition might be not unified but the importance and role of non-profit organizations (NPOs) is more than clear. They provide public services with the ability to respond to demand heterogeneity, e.g. they provide services that public sector is not capable to provide in full quality and quantity and private sector is not interested in providing these services as they are not profitable (Weisbrod, 1988; Pestoff, 2006). NPOs do not only provide public services but they are also watch dogs of the society and builders of active citizenship (Kuvíková in Zimmer, 2004). In this paper we mostly focus on this part of the role of NPOSs in the society, their watch dog activities and active participating in the civil society that influences the social cohesion in any country.

In Scandinavia there are countries where state organize and finance education, social and health care. Non-profit organizations in these countries are in addition to state care. Under the influence of economic pressure and social reforms from the last few years the governments of these countries have started to work more closely with NPOs. Non-profit sector in Iceland have been shaped by several theories (for general description of the theories see e.g. Gkarabelová ï Vaceková, 2013) and it fits into several models as characterised by Salamon ï Anheier (in Kuvíková, 2004) and Hyánek (2012). In the past it was mostly typical by a strong role of the state that serves its own interests or the interests of economic elites. In this so-called ñetatisticò model NPOs are as representatives of marginal interest pushed to the periphery. Under the mentioned economic pressure in 1990s' it turned into the "social democratic" welfare state of the Nordic countries characterized by universalism and a separation of welfare provision from the market system. Lately we can talk about the "corporatist" welfare state more common on the continent of Europe in which the state supplies welfare assistance but a strong state retains NPOs as a reserve to avoid more radical demands for government subsidies. The result is quite extensive for-profit sector with a current existence of social programs supported by the state. Other authors (Hrafnsdóttir, Kristmundsson, 2010) describe non-profit sector in Iceland as ñsupplementary relationsò that reflect the situation when non-profits simply are responding to unmet demands for public goods not fulfilled by the government. One of such unmet demands is a need to build a social cohesion within Iceland.

In developed countries the changes caused by globalisation are increasing and reflecting into changes in the cohesion of society. These include changes in technology, decision-making, social structure and social protection system. Iceland is facing an increasing number of immigrants: 7071 immigrants out of the population of 321857 mean only $2.2 \%$ but mostly they are concentrated in the capital, Reykjavik. The immigrants bring with themselves their culture and traditions which lead into growing diversity of society, including growing the risk of fragmenting society and deepening the processes of social exclusion. The immigrants are from various parts of the world, top ten countries are shown in Table 1 . 
Tab. 1: Migration to Iceland from top ten countries

\begin{tabular}{|l|l|}
\hline Poland & 1315 \\
\hline Denmark & 1112 \\
\hline Norway & 757 \\
\hline Sweden & 604 \\
\hline United States & 368 \\
\hline Germany & 317 \\
\hline United Kingdom & 265 \\
\hline Spain & 202 \\
\hline Lithuania & 158 \\
\hline France & 122 \\
\hline & \multicolumn{2}{|c|}{ Source: Statistics Iceland, www.statice.is }
\end{tabular}

As we can see, the most dominant population of immigrants is from Poland that has very different culture compared to Iceland. The following three Nordic countries (Denmark, Sweden, and Norway) might not have big problems with melting within the Icelandic society; other countries represent again different cultures. Members of particular communities or groups may be discriminated which ultimately undermines the cohesion of society as a whole. Immigrants are also seen as a thread on the labour market, especially after the economic crisis in 2008 - 2009 when the nationalization of the leading banks followed the collapse of the banking system in Iceland and the country had to apply for a financial aid to International Monetary Fund (Hrafnsdóttir, Kristmundsson, 2010). In year 2009 the unemployment was $7.2 \%$, an increase by $4.2 \%$ compared to previous year and in 2010 it was even higher on the level of $7.6 \%$ (Statistics Iceland). Naturally, the Icelandic society became more aware of immigrants and hostile attitude started to prevail.

We agree with Vagel ka (2003) who says that in a state inhabited by diverse communities with different cultures and traditions it is very important and effective binder stable social structure and related kinship relationships expressed as a common group identity, relations of solidarity manifested in the social protection system and relations of cooperation manifested by group action when addressing common challenges and problems. With the increasing diversity and differentiation of society is also growing a diversity of needs and interests of communities and socially, culturally or ethnically different groups. The need for effective cooperation and forming social cohesion has come to the fore. Parliament or state institutions are not often suitable for dialogue whose purpose is to find the underlying problem and find its solution before there is some degree of conflict or serious social problem. As an effective tool seems to be develop platforms, especially on the ground of nongovernmental and non-profit third sector organizations that provide welfare services to ease the possible conflicts (Kuvíková - Raguseo, 2008). Also Weisbrod (1988) argues that preferences of heterogeneous groups are not reflected in public policies and sooner or later, minorities will unite in different types of associations (NGOs, NPOs platforms) to meet their own needs and eventually they will force government to respond to them by establishing new public programs.

The non-profits provide important services and do steps in order to combat xenophobia and intolerance in everyday interpersonal relationships and activities of extremist groups. NPOs enter into a public space where it is necessary to present and defend an interest group (e.g. group of immigrants), look openly at the problems and seek their solutions.

\section{Goal and methodology}

The goal of this paper is to map the non-profit sector, its operation and contribution to regional development in the context of social cohesion in specific conditions in Iceland. We do not have the ambition to measure the impact of the NPOs operation on the decrease of negative phenomena connected with social incohesion; our qualitative research was mostly oriented to identifying 
successful organizations whose activities have brought positive results in the society. Furthermore we try to use the case of Iceland as a positive example in solving problems of social cohesion in Slovak republic. Iceland was chosen for several reasons; one of them is a partnership of the author of this paper with an Icelandic NPO Island Panorama that works to build a tolerant, non racial, non prejudiced, non discriminative society where social justice and equality exist for all. Another reason is the fact when the first refugees came to Iceland (about 34 years ago), the country started to solve the issue immediately and the government took steps by implementing laws and also by involving municipalities into creating the conditions for foreigners and educating natives about accepting the differences. Later on this role has been taken over by non-profit organizations in co-operation with the government (similar situation as in Slovakia, where the strong state took care about everything during the communism and after the change of regime the civil society had to learn how to solve many issues by themselves but unlike in Iceland, in Slovakia the support for NPOs and co-operation from the government side was not so significant in the beginnings).

As for the methods we used semi-structured interview with CEOs or directors of selected non-profit organizations in Iceland. These non-profits act in the areas of human rights and welfare in order to build social cohesion in the country either as service organizations or as watch dog (campaigning) organizations. The non-profits were selected based on the recommendation of the Human Rights Office in the Reykjavik City Hall who co-operates with other NPOs and on the recommendation of the Human Rights Centre that is an umbrella organization for NPOs active in this field. During December 2013 we visited thirteen recommended organizations and conducted semi-structured interviews with their chairmen or directors in order to learn about their operation and contribution to regional development in the context of social cohesion. Thus we use the answers with a method of good practices as examples for further inspiration what can be done in this area by non-profits in other countries.

Most of the respondents have a legal form of an association (7 organizations), then 4 are established as charities and last 2 participants have a form of public benefit organization. Nearly all participating organizations are active for more than 15 years $(84 \%)$, more detailed structure of the age of the respondents can be seen in chart 1 :

Fig. 1: Length of experience of the respondents

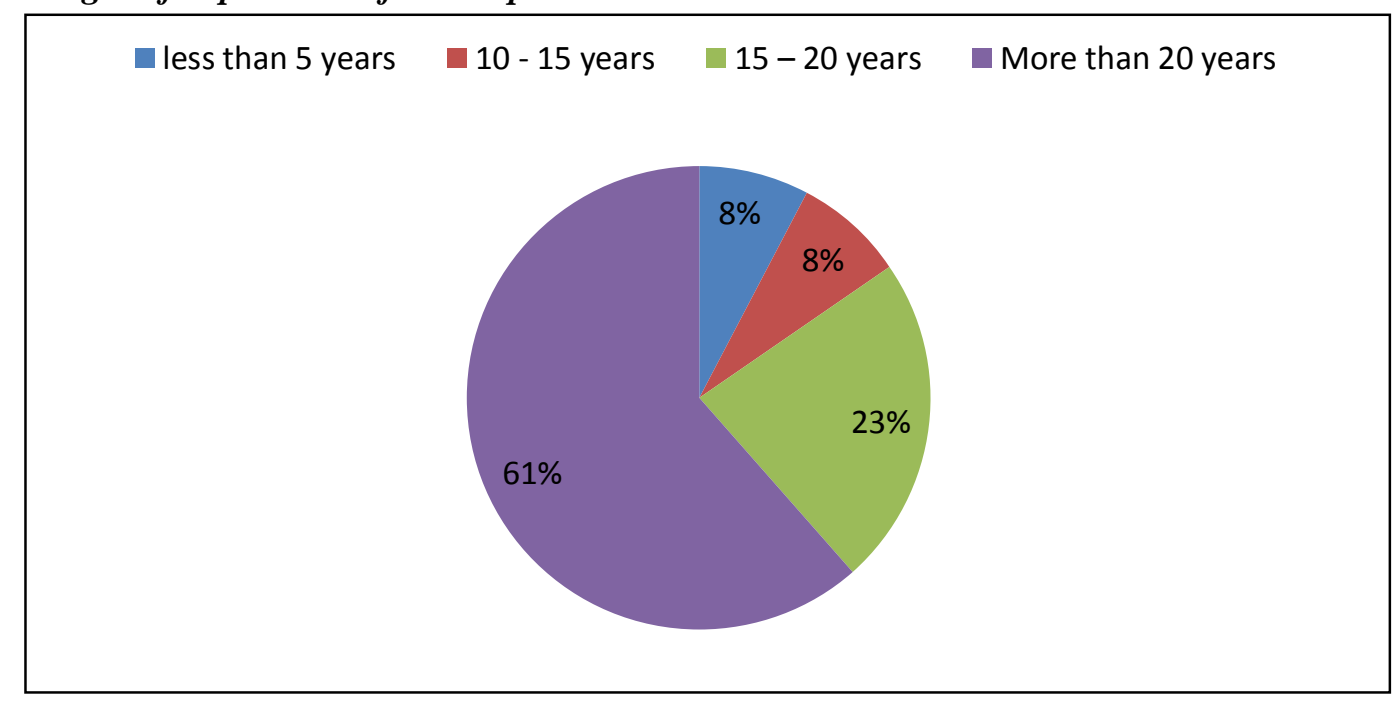

Source: own research, 2013.

As we can see on the chart the responding NPOs have been active in the ñmarketò of non-profit services for a long time. Based on this fact we can say they are stable in their operation, well-known and respected as a partner for government. We believe that particular activities of researched NPOs can be used as an inspiration in the countries of Central and East Europe as well. 


\section{Results}

Based on our research we are bringing the results about the operation of NPOs but also information about the funding and the co-operation with the government in building the social cohesion. Due to the limited scope of this paper the selected operation of NPOs is structured in Table 2 as the most important and/or dominant activities these organizations do in order to fulfill their mission. Their mission and core work activities directly or indirectly influences the social cohesion, Table 2 briefly summarises the answers that can be seen as an examples of good practices and serve as an inspiration for non-profit organization in other countries with similar mission and core work that seek to solve problems with immigrants, racism and discrimination and other issues that threaten the social cohesion in their countries.

\section{Tab. 2: Operation of the respondents ï activities of good practice}

\begin{tabular}{|c|c|}
\hline \multirow{9}{*}{ Human rights area } & Infusion into human rights awareness raising \\
\hline & $\begin{array}{l}\text { Organising a week long campaign against racism with } \\
\text { participation of many volunteers and wide public }\end{array}$ \\
\hline & $\begin{array}{l}\text { Free legal counselling for foreign nationals (help immigrants with } \\
\text { general information, obligations and rights in Iceland, work-related } \\
\text { issues etc.) }\end{array}$ \\
\hline & $\begin{array}{l}\text { Control of the activities of government and municipality, } \\
\text { commenting on legislation, drawing attention to causes }\end{array}$ \\
\hline & $\begin{array}{l}\text { Networking with other NPOs in creating joint programmes and } \\
\text { campaigns }\end{array}$ \\
\hline & $\begin{array}{l}\text { Creating a meeting place which supports cultural connections } \\
\text { between Iceland and the other Nordic countries but also invites } \\
\text { different nationalities who came to live to Iceland to explore } \\
\text { Icelandic history and culture }\end{array}$ \\
\hline & $\begin{array}{l}\text { Increasing communication and co-operation between immigrants } \\
\text { and Icelanders and encourages a harmonious multicultural society } \\
\text { in Reykjavik by coordinating events and supporting cultural } \\
\text { groups seeking to organize their own events and projects }\end{array}$ \\
\hline & Heritage language instruction \\
\hline & $\begin{array}{l}\text { Research of the law in Iceland, in the Nordic countries and of the } \\
\text { EU law focused on the extent to which anti-discrimination law in } \\
\text { Iceland meets the current requirements of EU law }\end{array}$ \\
\hline \multirow{5}{*}{$\begin{array}{l}\text { Welfare services area (social care, health } \\
\text { care, education) }\end{array}$} & $\begin{array}{l}\text { Changed the law and the regulations of the society and created a } \\
\text { wake up moment about the rights of children from marginalised } \\
\text { groups (e.g. divorced parents, immigrant parents etc.) }\end{array}$ \\
\hline & $\begin{array}{l}\text { Establishing a multi-functional service centre that provides wide } \\
\text { range of services which helps to raise funds in more effective way }\end{array}$ \\
\hline & $\begin{array}{l}\text { Creating an action plan that empowers the co-operation between } \\
\text { city of Reykjavik agencies, government and NPOs }\end{array}$ \\
\hline & Building long-term contracts with the government \\
\hline & $\begin{array}{l}\text { Support multiculturalism and combat racism and discrimination at } \\
\text { public schools in collaboration with the management of these } \\
\text { schools. }\end{array}$ \\
\hline
\end{tabular}

Source: own research, 2013.

As the table 2 shows, the NPOs in Iceland use a variety of actions and tools in order to support the social cohesion. Either it is direct provision of services to immigrants and minority groups to help them with the inclusion and thus prevent in emergence of any conflicts or the activities of watch-dog and campaigning organization that comment on legislation and draw attention to different causes. In their first stages of operation campaigning organizations were informal and unstructured but have developed over time into large formal organizations and even into umbrella organizations and multifunctional centres. We found this as a very important step so the NPOs can benefit from the ability to co-operate with each other, networking and joint project with other NPOs and/or with the government 
can be very beneficial in building the social cohesion. Also Hamalová et al (2012) see co-operation and partnership as a strategic tool in realisation of development incentives in regions.

These activities must be financed as any other activities in any sphere, commercial or non-profit; the costs must be always covered. Non-profit organizations globally are aware of the need to diversify their funding (Vaceková, 2013). Participating NPOs have the structure of the funding as follows:

Fig. 2: Funding of the respondents

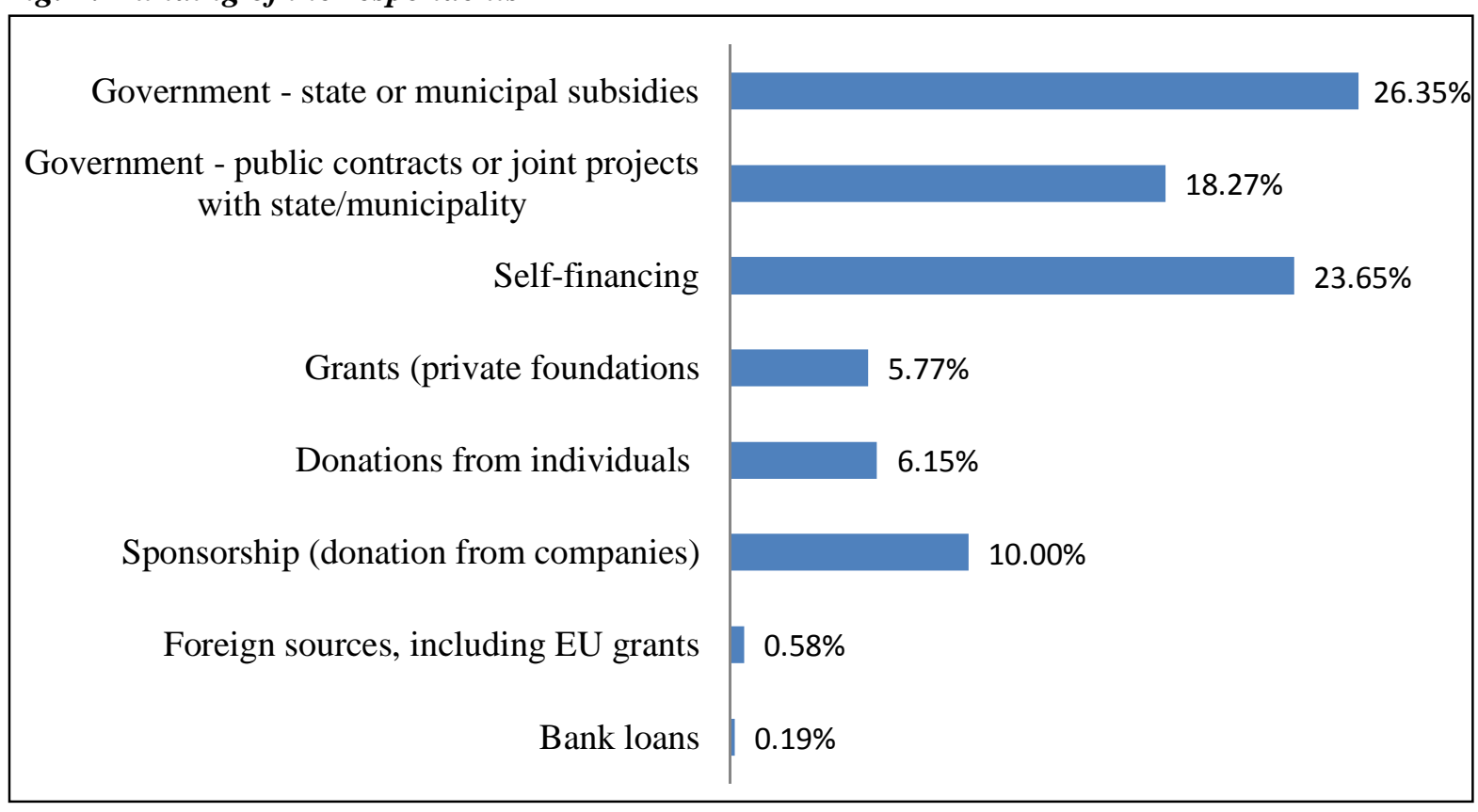

Source: own research, 2013.

From the chart 2 it is obvious that respondents do not use only public sources although they provide public services. The respondents use public subsidies either from state or local level or both at the level of $26 \%$; another public funding is distributed via contracts or joint processes (18\%). This means that bigger part of the funding is from private sources (46\%), e.g. self-financing and donations from companies and individuals. Therefore the demands on public budgets (state or municipality) are decreased and these NPOs find also other sources for financing their activities that contribute to social cohesion.

\section{Conclusion}

In this paper we have shown the role of non-profit organization in Iceland in building the social cohesion. It was also thanks to the non-profit sector that the economic crisis from 2008 did not last for too long. The activities of NPOs among other things helped to stabilise the situation, the government did not have to solve open conflicts; they found other sources of funding which decreased the demand on public budgets and more financial aid could be directed into solving the unemployment (the rate of $7.6 \%$ in 2010 was decreased to $7.1 \%$ in 2011 and dropped even more in following years to $6 \%$ in 2012 and $5.4 \%$ in 2013). With their activities NPOs are changing the view on immigrants so these are not perceived as a thread and they also help immigrants to integrate into Icelandic society. Some of the NPOs have become highly influential in policy making in Iceland when they have formed a network of organizations that have gained a powerful role in the policy-making process influencing new legislation.

As for Slovakia, Vagel ka (2003) predicts that in the horizon 2020 the importance of not only social but also a variety of intercultural and interethnic conflicts and problems will increase. In Slovakia there are a few communities, e.g. Roma, Jewish, Ruthenia, Carpathian Germans etc., and new 
communities have started to emerge (Vietnamese, Muslims). To search social contract and raise the level of social cohesion, a platform of civil society organizations of the third sector is needed. This platform would address the challenges of building a non-ethnic global society in Slovakia. One of the important steps is to learn the communities (and all citizens) that the state cannot provide public services and social protection in full range; the changes in state social support are necessary. The inspiration can be found in the case of Iceland where different communities and different cultural and social groups formed thanks to the activities of NPOs. They learnt to formulate, implement and enforce their needs and interests and they found a way of communicating with each other and with the government so the social cohesion within the country is strengthened.

\section{References}

[1] External migration by sex, countries and citizenship 1986-2013., (2012). [online]. [cit. 2014-3-28]. Dostupné z: < http://www.statice.is/>.

[2] HAMAlOVÁ, A., BELAJOVÁ, A. KOVÁCSOVÁ, I., (2012). Attitudes of the self-government and entrepreneurs to the partnerships cooperation and examples of good practice. In 15th International Colloquium on Regional Sciences. Conference Proceedings. Brno: Masarykova univerzita. pp. 353-362. ISBN 978-80-210-5875-0.

[3] HRAFNSDÓTTIR, S. KRISTMUNDSSON, Ó. H., (2010). Challenges in the Icelandic Non-Profit Sector. In ISTR 9th International konference. Facing Crises: Challenges and Opportunities Confronting the Third Sector and Civil Society. WORKING PAPERS SERIES VOLUME VII. Istanbul: Kadir Has University.

[4] HYÁNEK, V., (2012). Neexistující sektor? Scientia et Societas. Praha: NC Publishing, vol. 4, pp. 4 -22. ISSN $1801-7118$.

[5] KUVÍKOVÁ in Zimmer, ZIMMER, A. PRILLER, E., (2004). Future of civil society. Making Central European Nonprofit-Organizations work. Wiesbaden: VS Verlag. ISBN 3-8100-4088-6.

[6] KUVÍKOVÁ, H., (2004). Neziskové organizácie v Európskej únii. Ekonomická fakulta UMB. ISBN 808055-937-6.

[7] KUVÍKOVÁ, H., RAGUSEO, D., (2008). The Economic Rationale of Non-profit Organizations in the Delivery of Welfare Services. Ekonomický !asopis / Journal of Economics, vol. 56, iss. 8, pp. 764-780. ISSN 0013-3035.

[8] PESTOFF, V., (2006). Co-Production, the Third Sector and the Delivery of Public Services: An Introduction. Public Management Review, vol. 8, iss. 4, pp. 493 ï 519. ISSN 1471-9045.

[9] SALAMON, L.M., ANHEIER, H., (1999). In search of the non-profit sector. Voluntas: International Journal of Voluntary and Nonprofit Organizations, vol. 3, iss. 2, pp. 125ï 151. ISSN 1573-7888. DOI 10.1007/BF01397770.

[10] VACEKOVÁ, G., (2013). Financial controlling in non-profit organizations. The case of Slovak Republic. Risk Governance and Control: Financial Markets \& Institutions, vol. 3, iss. 2, pp. 49-57. ISSN 2077429X.

[11] VACEKOVÁ, G., GKARABELOVÁ, S., (2013). The role of third sector organizations in rural development. In 16th International Colloquium on Regional Sciences. Conference Proceedings. Brno: Masarykova univerzita. pp. 549-556. ISBN 978-80-210-6257-3. DOI 10.5817/CZ.MUNI.P210- 62572013-69.

[12] VAǴEL KA, I., (2003). Sociálna súdrǵnosŠ sociálne vzŠihy, sociálna ğruktúra. In Vízia vývoja Slovenskej republiky do roku 2020. První. Bratislava: Inġitút pre verejné otázky. ISBN 80-88935-42-3.

[13] WEISBROD, B.A., (1988). The Nonprofit Economy. Cambridge: Harvard University Press.

The paper is a part of the project FB-1-07 ñ Love your haterò supported by the programme Active Citizenship and Inclusion within the EEA Financial Mechanism 2009-2014, funded by Iceland, Liechtenstein and Norway, in Slovakia realized by consortium led by the Ekopolis Foundation, in partnership with the Children of Slovakia Foundation and the Socia Foundation and Human rights and democracy. 